\title{
Influence of Socio-economic Characteristics of Farmer-Subscribers on Utilization Pattern of Kisan Mobile Advisory Service (KMAS) in Banaskantha District of Gujarat State, India
}

\author{
K.V. Patil ${ }^{*}$, V.T. Patel ${ }^{2}$ and J.K. Patel $^{2}$ \\ ${ }^{1}$ Department of Agricultural Extension, PJTSAU, Hyderabad, Telangana -500030, India \\ ${ }^{2}$ Department of Extension Education, SDAU, Sardarkrushinagar, Gujarat -385506, India \\ *Corresponding author
}

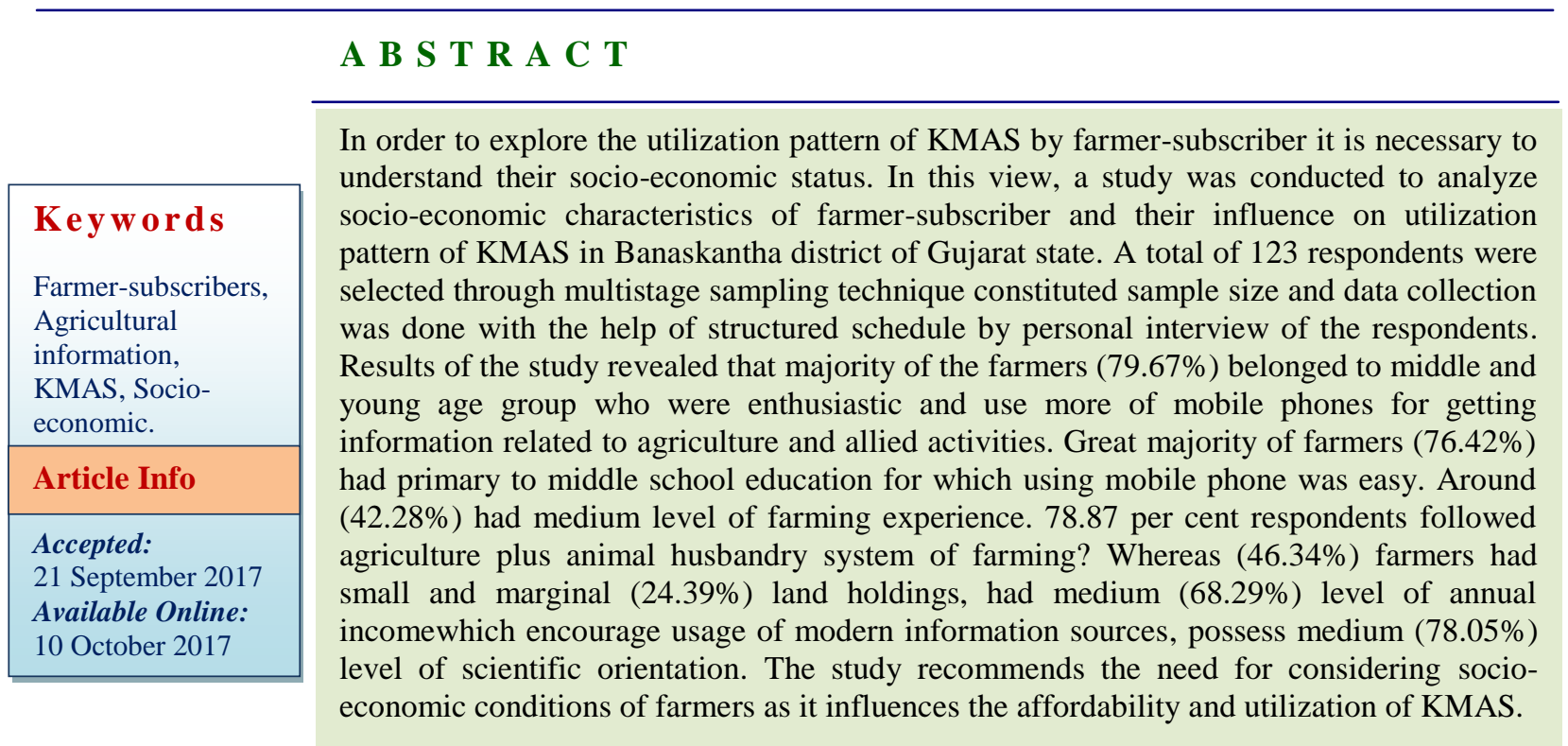

\section{Introduction}

Information is critical in agricultural development because it is a tool for communication between stakeholders and serves as a channel for assessing trends and shaping decisions (Kalusopa, 2005). Small and marginal farmers, who are the vast majority of Indian farmers, are often unable to access information that could increase yields and lead to better prices for their crops. Ushering agriculture development extension has to play extended role to provide access of information and services on market research, credit and development of farmer's organizations for marketing of produce. The modern Information Communication Technologies (ICTs) as mobiles and computers have created a revolution. In the $21^{\text {st }}$ century, cost effective and efficient communication technologies are required to take lead in changing agricultural scenario.

The government has a huge research and development infrastructure in the form of institutions such as the Indian Council of 
Agricultural Research (ICAR), State Agricultural Universities (SAUs), Krishi Vigyan Kendras (KVKs) and Agriculture Technology Management Agencies (ATMAs). The role of this set-up in research and extension activity is of great importance. The use of Kisan Mobile Advisory Service (KMAS) scheme in front line extension system of Krishi Vigyan Kendra's is new ICT initiatives to meet the information needs and expectations of the farmers.

KMAS is started by ICAR with the aim of passing the agricultural information to maximum number of farmers in local language through SMS free of cost. It is operated by KVKs all over the India. Subject areas of KMAS are Agronomy, Plant protection, Horticulture, Animal science, Home science, Dairy, etc. Advantages of KMAS are farmers can get free information, location specific information delivery, provide information in local language and cost effective. KMAS has been launched in $192 \mathrm{KVK}$ all over India and KVK Deesa is one of the KVK selected for implementation of scheme. KVK is using Kisan Portal, Ministry of Agriculture, Government of India to send the SMS to the farmers.

The use of KMAS by farmer-subscriber is affected by their socio-economic status. So keeping these points in mind the study was mainly focused to reveal the socio-economic variables associated with the farmers of Banaskantha district.

\section{Materials and Methods}

The study was confined to ex-post facto research design as the independent variables have already made impact on utilization of ICT that was studied by the researcher (Kerlinger, 1976).Multi stage sampling technique was employed in the study. The study was conducted in Banaskantha district of Gujarat state, where Krishi Vigyan Kendra
(KVK) is providing agricultural technological knowledge through KMAS. KVK Deesa is selected by ICAR for mobile advisory services among $192 \mathrm{KVKs}$ selected in first phase since 2009. The area of work of KVK Deesa is Banaskantha district, hence it was selected purposively. Banaskantha district comprises of 14 talukas. Out of these six talukas were purposively selected on the basis of more number of subscriber farmers of KMAS. Three villages from each selected taluka were purposively selected on the basis of higher number of subscriber farmers of KMAS. Village wise list of subscriber farmers was obtained from KVK Deesa. Random sampling method was used in selection of respondents in proportion to 30 per cent of the subscribers from each selected village. Finally, a sample of 123 farmers was drawn from the population. The data were collected with the help of structured schedule by personal interview of the respondents.

\section{Results and Discussion}

The results of the investigation carried out are presented through the Table 1 showing the socio-economic characteristics of farmers who have opted KMAS as source of information and use it for information. It could be observed from table 1 that majority of the farmers (79.67 per cent) belonged to middle and young age group. The probable reason of the finding might be that, middle and young aged people are enthusiastic and use more of mobile phones for getting information related to agriculture and allied activities. Moreover, these people have more family responsibility and sensibility. They also work with a sense of commitment and involvement (Patil, 2016).

Results pertaining to the education indicated that great majority of farmers (76.42 per cent) had primary to middle school education. This might be due to that farmers have easy access to schools in their own villages or nearby 
villages and realization of importance of formal education in the present situation. As they had education, they were able to use mobile phones easily and gather knowledge on recent technologies disseminated through KMAS.

With respect to farming experience, majority of farmers belonged to medium to moderately high (61.79 per cent) farming experience category. This mainly depends upon age as majority of the farmers in the present study belonged to young and middle age category so, they might have started farming at an early age itself.
The results shows that more than three fourth of the farmers (78.87 per cent) had followed agriculture + animal husbandry system of farming. It is obvious that agriculture + animal husbandry farming system is prevalent in the study area as dairy cooperative network is well established in North Gujarat. Hence, a large segment of farmers under study found, following these farming systems jointly.

The study reveals that majority of the farmers had small and marginal land holding. This might be due to fragmentation of land among of the members of the family resulting into high numbers of small and marginal farmers.

Table.1 Profile characteristics of farmer-subscribers of KMAS

$(n=123)$

\begin{tabular}{|c|c|c|c|c|}
\hline S. No. & Variables & Category & Frequency & Percentage \\
\hline \multirow{3}{*}{1} & \multirow{3}{*}{ Age (in year) } & Young (Up to 35$)$ & 38 & 30.89 \\
\hline & & Middle (36-50) & 60 & 48.78 \\
\hline & & Old (Above 50) & 25 & 20.33 \\
\hline \multirow{6}{*}{2} & \multirow{6}{*}{ Education } & Illiterate & 09 & 07.32 \\
\hline & & Functionally literate & 02 & 01.63 \\
\hline & & Primary school & 58 & 47.15 \\
\hline & & Middle school & 36 & 29.27 \\
\hline & & High school & 07 & 05.69 \\
\hline & & College or Post Graduate & 11 & 08.94 \\
\hline \multirow{4}{*}{3} & \multirow{4}{*}{$\begin{array}{l}\text { Farming } \\
\text { experience }\end{array}$} & Low (upto 10 years) & 33 & 26.83 \\
\hline & & Medium (from 11 to 20 years) & 52 & 42.28 \\
\hline & & Moderately high (from 21 to 30 years) & 24 & 19.51 \\
\hline & & High (above 30 years) & 14 & 11.38 \\
\hline \multirow{5}{*}{4} & \multirow{5}{*}{ Farming system } & Agriculture & 04 & 03.25 \\
\hline & & Animal husbandry & 01 & 00.81 \\
\hline & & Agriculture + Animal husbandry & 97 & 78.87 \\
\hline & & Horticulture + Animal husbandry & 01 & 00.81 \\
\hline & & $\begin{array}{c}\text { Agriculture + Horticulture + Animal } \\
\text { husbandry }\end{array}$ & 20 & 16.26 \\
\hline \multirow{4}{*}{5} & \multirow{4}{*}{ Land holding } & Marginal (up to $1.00 \mathrm{ha}$ ) & 30 & 24.39 \\
\hline & & Small (from 1.01 to $2.00 \mathrm{ha}$ ) & 57 & 46.34 \\
\hline & & Medium (from 2.01 to $4.00 \mathrm{ha}$ ) & 26 & 21.14 \\
\hline & & Big (above $4.00 \mathrm{ha})$ & 10 & 08.13 \\
\hline \multirow{3}{*}{6} & \multirow{3}{*}{ Annual income } & Low (below Rs. 0.15 lakhs) & 22 & 17.89 \\
\hline & & Medium (from Rs. 0.15 to 3.53 lakhs) & 84 & 68.29 \\
\hline & & High (above Rs. 3.53 lakhs) & 17 & 13.82 \\
\hline
\end{tabular}


Table.2 Distribution of the farmer-subscribers of KMAS according to their scientific orientation

\begin{tabular}{|c|l|c|c|}
\hline Sr. No. & \multicolumn{1}{|c|}{ Scientific orientation } & Frequency & Percentage \\
\hline 1. & Low (below 19.55 score) & 12 & 09.76 \\
\hline 2. & Medium (from 19.55 to 24.95 score) & 96 & 78.05 \\
\hline 3. & High (above 24.95 score) & 15 & 12.19 \\
\hline \multicolumn{2}{r}{ Total } & $\mathbf{1 2 3}$ & $\mathbf{1 0 0 . 0 0}$ \\
\hline
\end{tabular}

Mean $=22.25$ S.D. $=2.70$

The results shows that majority of the respondents had medium level of annual income. It might be due to the animal husbandry enterprise which give higher and assured income and practicing of more than one farming systems / enterprises by the farmers.

It could be seen from Table 2 that more than three fourth farmers possess scientific approach and this might be due to their faith in using various scientific management practices of crop production with efficient resource management in farming.

A critical analysis of socio-economic characteristics of farmers who use KMAS revealed that majority of farmers belong to middle and young age group and majority of young farmers happened to be small and marginal farmers. Since most of the farmers are middle to young aged, as they will be enthusiastic we can reinforce their entrepreneurial behavior by providing attractive and relevant information through KMAS. Majority of farmers had primary to middle school education status so it is easy to use mobile phones and gather knowledge on recent technologies disseminated through KMAS. It can reduce the burden on insufficient extension personnel. It is also revealed that majority of farmers depend on combination of cropping systems for their income rather than single cropping patterns. More than three fourth farmers possess scientific approach so it necessary to provide user friendly, sustainable, scientific, location specific technology generation is necessary to meet the needs.

\section{Acknowledgement}

I would like to thank my chairperson Dr. V. T. Patel for guiding me throughout my research study. I thank Department of Extension Education, SDAU, Sardarkrushinagar for allowing me to pursue my research study. I thank all the farmers who gave suitable information for the research study.

\section{References}

Kalusopa, T., 2005. The Challenges of Utilizing Information and Communication Technologies (ICT's) for the small scale farmer in Zambian. IN: Library Tech, 23(3) 414-424, www.emeraldinsight.com/0737-

8831.htm. Retrieved on 8th January, 2011.

Kerlinger, 1976. Foundation of Behavioral Research. Surjeet Publication, Delhi. pp. 129.

Patil, K.V., 2016. Utilization pattern of Kisan Mobile Advisory Service by the farmers of Banaskantha district. M. Sc. Thesis. Sardarkrushinagar Dantiwada Agricultural University, Sardarkrushi nagar (India).

\section{How to cite this article:}

Patil, K.V., V.T. Patel and Patel, J.K. 2017. Influence of Socio-economic Characteristics of FarmerSubscribers on Utilization Pattern of Kisan Mobile Advisory Service (KMAS) in Banaskantha District of Gujarat State. Int.J.Curr.Microbiol.App.Sci. 6(10): 2377-2380.

doi: https://doi.org/10.20546/ijcmas.2017.610.280 